THURSDAY, OCTOBER 7, 1880

\section{THE PLACE OF SCIENCE IN EDUCATION}

$T$ HERE has been a great deal said and written on the subject of education during the past week. First of all we have the important address of Prof. Huxley at the opening of the Mason College, Birmingham, which we give in full on another page; then there is the brief but significant address of Sir Stafford Northcote at Tiverton; and lastly, the summary of Sir Charles Reed of the ten years' work of the London School Board. All this has furnished ample food for comment in the daily papers, and their misconceptions as to the real drift of Prof. Huxley's address must be amusing to those who know what science really means, and what are the opinions held by reputable men of science as to what constitutes sound and complete cducation. With regard to the institution which has been so generously founded and handsomcly endowed by Sir Josiah Mason at Birmingham, it should be remembered that there was no intention to start it as a university. Its founder has had to push his way through life, and notwithstanding the unusual success of his career, he confesses that he has but little faith in the ruleof-thumb method, which was often his only guide. At every step, he admits, he was hampered and hindered by the want of scientific knowledge, by his ignorance of those exact methods, those laws and facts, which can only be satisfactorily acquired and utilised by a preliminary scientific training. Even at his advanced age the consciousness of this want is so strongly impressed upon him that, with true benevolence and rare generosity, he has founded the magnificent institution at Birmingham which was opened last Friday, in order that succeeding generations of boys may have a chance of equipping themselves at the outset with those weapons of precision, the want of which he who has fought successfully the battle of life had to deplore at every step. The Mason College at Birmingham is not a mere technical institute, as may be seen from our article in NATLRE, vol. xxii. p. 514, in which the course of instruction provided is deseribed. All departments of science are provided for, as well as certain special applications of some of them; the great principles and facts of these sciences first, and their special application afterwards. Wisely also the founder has provided for instruction in the English, French, and German languages; and even, as Prof. Max Miiller stated in his brief but admirable address at the luncheon, for Greek and Latin. The deed of foundation makes ample provision for the widening of the programme, the extension of the subjects taught, and the adaptation of the institution to the timcs. Special reference is made to art, which will no doubt be added. At the same time the founder excludes from his programme "mere literary education." It is, we suppose, this exception-which looking at the programme of the College, seems to us somewhat vague-that has led the daily press to misconceive Prof. Huxley's address as a defence of science as a means of education, to the entire exclusion of literature. What Prof. Huxley maintains, as we read his address, and as we read his other utterances on the same point, is, that if a man is to VoL. xxII,-No. 571 have an education in only onc aspect of things, then by all means let it be the scientific aspect; on the other side he can educate himself at his leisure, whereas, as Sir Josiah Mason forcibly testifics, when a man gets into the thick of the fight, it is all but impossible for hirn to make up for the want of scientific training in his youth. As a mental discipline and a means of culture science by itself is as good an implement as literature by itself, and probably a great deal better, as the former takes us into the very heart of nature in its widest sense, while the latter only deals with the outside of things. At the same time I'rof. Huxley expressly states that exclusive training in either the one direction or the other is esscntially lopsided, and not to be encouraged that it is essential to the completeness of a man's culture that it should have an $x$ sthetic and literary, as well as a scientific side; and what other opinion could be held by one who himself seems familiar with "the best that has been said and thought" in all the languages of culture. We are much mistaken if Prof. Huxley would not endorse every word spoken by Prof. Max Miiller, on the necessity for the study of the science of man, the science of thinking and of speaking, to a completely liberal education. The truth is that there is a widespread misconception as to what science really means; we have been so long aceustomed to apply the term to certain groups of concrete facts, that we forget that it may be applied, and indeed is now frequently applied, to any branch of knowledgc investigated on the method which has been so fruitful in the study of physical phenomena. Science indeed is merely the counterpart of sentiment; each of them has its proper place, and each of them is indispensable to the complete development of the humari mind. To neglect training on either the one side or the other must produce an imperfect, a lop-sided result; but there is no reason why cither should be neglected. Let the programme of elementary education only be developed in the direction so long advocated by Sir John Lubbock and those whe think with him, and let the whole of the education of the country up to our colleges and universities be carricd out on the same lines, and every side of the human constitution and every aspect of human learning will have fair play. Prof. Huxley did well to defend science as a method of mental discipline certainly equal to the old and merely literary methods which so long prevailed at our universities, and which have been so abused; but his address will be strangely misread if any idca of suppressing the old learning is attributed to him. It is interesting to notice that Sir Stafford Northcote, in his short address at Tiverton, followed the plan of that of Prof. Huxlcy, beginning by strenuously advocating the spread of scientific education in the country as the only means by which wc can bc able to cope with our neighbours, and concludingr by maintaining that it would be a serious mistake to suppress literary training entirely. This is what we have all along maintained in these pages, and we are sure that Prof. Huxley is on our sidc. Science has had a hard fight to obtain a place in the education of the country, and she has not yet obtained the place she is entitled to; she will only have done 60 when in all our educational institutions she holds a position of perfect equality alongside of the subjects which until recently monopolised our 
schools and colleges, and we trust that when another decade's work of the London or any other School Board has to be summarised, the so-called extra subjects will have become an integral part of the elementary education of the country. Such institutions as that opened at Birmingham will greatly help on the cause of scientific education. The standard of teaching we are glad to see is high, the best science schools of the Continent being taken as models; and we trust the Mason College will never degenerate into a mere technical training-school. Under the liberal principles for its conduct laid down by the founder, it is capable of the widest development in every direction; whether it may form the nucleus of a Birmingham University remains to be seen. Its working will be watched with the greatest interest by all who have at heart the raising of the standard of education in the country.

\section{CHEMISTRY OF THE CARBON COMPOUNDS}

Elements of Chemistry. By William Allen Miller, M.D., \&c. Revised and in great part re-written by Henry E. Armstrong, Ph.D., F.R.S., and Charles E. Groves, F.C.S. Part III.--Chemistry of Carbon Compounds, or Organic Chemistry. Section I.-Hydrocarbons, Alcohols, Ethers, Aldehydes, and Paraffinoid Acids. Fifth edition. (London: Longmans, Green and Co., 1880.)

T HE study of the laws governing the combinations of molecules containing carbon is of the very first importance to chemical science, inasmuch as this study so well illustrates and extends the general laws of molecular combinations, that is to say, the general laws of the science of chemistry.

An almost innumerable array of facts concerning carbon compounds is to be found in the ordinary text-books; papers in the chemical journals sometimes contain generalisations drawn from certain classes of those facts: the later supplements to Watts's "Dictionary" contain the more important of the comparatively recent generalisations; but there has undoubtedly existed for some time among students of chemistry a wish for a textbook in which the leading facts concerning the compounds of carbon should be clearly stated, the general properties of, and general relation between groups of these bodies should be indicated, and summaries of the evidence in favour of or against the generally adopted structural formulæ of the more important compounds should be presented to the student, in order that he might thus have in one text-book such a fair compendium of the present state of this branch of the science as should furnish him with suggestions for work, by showing him what is clearly known, where exact knowledge ceases, and where even analogy lends but little help.

The first part of such a text-book English chemistry now possesses; let us hope that the second part of this admirable book will soon follow, and be worthy of that now published.

In their preface the editors-had we not better say at once the authors?-write: "Notwithstanding the extraordinary increase in the number of the carbon compounds, their study is gradually becoming simplified as the possibility is extended of arranging them in series and of giving a general description of their chief properties applicable to all the members of the group."

There can be no hesitation in saying that the authors' work-more than any other text-book in the English language-will aid the advance of this, the only true method, of studying Organic Chemistry.

There are text-books of Organic Chemistry which tell the student that the structure of this or that compound "is represented by the following formula"; this book follows another and a better plan: the authors give a succinct and clear sketch of the evidence for and against all important structural formulæ, thus indicating the true value of these formulæ as condensed statements of chemical facts, and at the same time setting before the student examples of the application of the chemical method of inquiry.

The general principles underlying the formation of so-called structural formulæ are adverted to in more than one place by the authors.

These formulæe are based on the laws of "atomlinking," which again are deductions from the theory of quantivalence or valency, itself an outcome of the application of chemical methods of inquiry to the molecular theory of matter.

Although the volume before us is Part III. of a large work, the first part of which deals with chemical physics, it would nevertheless, we think, have been advisable to have given a brief sketch of the molecular theory of matter, and to have shortly stated-but more fully than is done on p. 42-the evidence on which is based the (chemically) all-essential difference between atom and molecule.

A little space might have been spared for an exposition of the laws of atom-linking, such as, but very much more condensed than, that in Lothar Meyer's "Modernen Theorieen."

In speaking of quantivalence, on p. 42 , the authors do not explicitly state that it is the atoms of the elements which "are equivalent in combining or replacing power to one, two, three, four, five, or six monad atoms of hydrogen." Of course this is implied throughout the discussion which follows, but students sometimes fail clearly to grasp the difference between the old chemistry, which attempted, but failed, to determine equivalent weights of elements, and the new, which is so largely based on the equivalency of groups of atoms of the elements.

Frankland's "bond" explanation of valency is sketched, but so long as we have no definite physical conception of what a "bond" is, this explanation really explains nothing; such an expression as "two of the bonds neutralise each other" has no meaning, further than that the valency varies from a given number to two less than this number.

The authors give some examples of compounds, which seem to show that the valency of certain elementary atoms may vary from an odd to an even number; but they do not give examples which prove such a variation, e.g., $\mathrm{MoCl}_{5}$ and $\mathrm{MoCl}_{6} ; \mathrm{WCl}_{5}$ and $\mathrm{WCl}_{6} ; \mathrm{NO}, \mathrm{NO}_{2}$ and $\mathrm{NH}_{3}$.

The authors, probably wisely, do not very definitely express their opinion as to the exact meaning of a structural formula; they sometimes appear to regard these formulæ as real representations of the relative 